\title{
Share-Option Based Compensation Expense, Shareholder Returns and Financial Crisis
}

\author{
Alaa Alhaj-Ismail ${ }^{1}$ \\ School of Economics, Finance and Accounting, Coventry University, UK. \\ Alaa.AlhajIsmail@coventry.ac.uk
}

\begin{abstract}
Sami Adwan
University of Sussex Business School, University of Sussex, UK.

S.Adwan@ sussex.ac.uk
\end{abstract}

John Stittle

Essex Business School, University of Essex, UK.

jstittle@essex.ac.uk

\section{ACKNOWLEDGMENTS:}

We acknowledge the invaluable comments and helpful suggestions received from Professor Peter Clarkson (Editor) and an anonymous reviewer. We would also like to thank Dr. Graham Sadler, Dr. Sailesh Tanna and Dr. Karl Shutes (Coventry University), Dr. Silvia Gaia (University of Essex) and the participants at the EAA 40th Annual Congress (Valencia, 2017) and at the Faculty of Business and Law Internal Research Annual Conference (Coventry, 2017) for their helpful comments and suggestions.

\section{FUNDING:}

This research did not receive any specific grant from funding agencies in the public, commercial, or not-for-profit sectors.

\footnotetext{
${ }^{1}$ Corresponding Author: Email: Alaa.AlhajIsmail@ coventry.ac.uk or ac2210@ coventry.ac.uk, Address: School of Economics, Finance and Accounting, Coventry University, WM324, Priory Street, Coventry, CV1 5FB
} 


\begin{abstract}
:
This paper contributes to the literature that analyses the relationship between Share-Option Based Compensation (SOBC) expense and shareholder returns. It utilises a sample of financial firms listed in the European Economic Area and Switzerland between 2005 and 2016 to make inferences about the impact of the financial crisis on the above-mentioned relationship. The paper also assesses the extent to which the relationship between SOBC expense and shareholder returns during the financial crisis varies with ownership concentration. We find evidence that the positive relationship between SOBC expense and shareholder returns is significantly more apparent during the financial crisis. This suggests that investors place more emphasis on the unrecognised intangible features of SOBC contracts during the crisis, even though their associated expenses are subject to managerial discretion and measurement errors. We also find that the positive relationship between SOBC expense and shareholder returns over the financial crisis is more pronounced when ownership is more concentrated. The results of our study are robust after controlling for firm size, potential investment growth opportunities, traditional banking activities and firm self-selection bias.
\end{abstract}

Keywords: IFRS 2, share-based payment, Share based compensation, financial institution, financial crisis, and large shareholders.

JEL classification: M41, J33, G01, G32 


\section{INTRODUCTION}

The financial reporting implications and economic consequences surrounding the mandatory recognition and measurement of the fair-value amount associated with Share Option-Based Compensation (hereinafter SOBC) ${ }^{2}$ schemes in the financial statements, under IFRS 2, have been a subject of widespread discussion internationally. ${ }^{3}$ A particular focus in the accounting literature has been given to assess the relationship between SOBC expenditure and company market value/return under alternative accounting treatments (e.g. Rees and Stott, 2001; Bell et al., 2002; Aboody et al., 2004; Niu and Xu, 2009; Matolcsy et al., 2009). Another stream of accounting literature has focused on the effect of financial crises on the market valuation of accounting information (e.g. Davis-Friday et al., 2006; Choi et al., 2011; Kousenidis et al., 2013). No study, however, has investigated whether the relationship between SOBC expense and company market value/return varies over the financial crisis. This paper contributes to the abovementioned two streams of literature. More specifically, it utilises a sample of financial firms listed in the European Economic Area and Switzerland over the period 2005-2016 to make inferences about the impact of the financial crisis $^{4}$ on the relationship between SOBC expense and shareholder returns.

Our study is motivated by the notion that companies utilise SOBC schemes to attract and retain

\footnotetext{
${ }^{2}$ IFRS 2 covers accounting for all types of share-based transactions in which the entity receives goods or services as consideration for its equity instruments or by incurring liabilities for amounts based on the price of the entity's shares or other equity instruments of the entity. A famous element of SOBC schemes is employee share options where the issued equity instrument gives the awarded employee the right, but not the obligation, "to buy a share of stock at a pre-specified 'exercise' price for a prespecified term" (Hall and Murphy, 2002, p. 2). SOBC packages commonly include share options, in addition to other similar equity awards, such as share purchase plans, as well as cash-settled awards where the cash payment depends on the share price as in the case of share-appreciation rights. In this study, we focus on all types of SOBC schemes awarded to both directors and employees as the most common beneficiaries of these schemes.

${ }^{3}$ Expensing the fair value of SOBC schemes over the vesting period is now mandated by two major accounting standard-setters, the International Accounting Standards Board (IASB) who issued IFRS2 in 2004, and the Financial Accounting Standards Board (FASB) who issued Statement of Financial Accounting Standards SFAS 123R (share-based payment) in December 2004. SFAS 123R was first applied to accounting periods ending in 2006.

${ }^{4}$ Throughout this paper, the terms "the financial crisis" and "the crisis," are used interchangeably referring to the period of $2007-$ 2011. This period covers both the 2007-global financial crisis as well as the Eurozone sovereign debt crisis that started at the end of 2009.
} 
experienced and skilled employees, the main driver of a company's intangible resources (Lev, 2001), especially in loss years (Schiemann and Guenther, 2013). The theoretical underpinning for SOBC contracts is the agency theory whereby appropriately designed SOBC contracts, given the assumption of self-interest behaviour, information asymmetry and risk-aversion, are expected to tie the interests of shareholders with those of managers. Designing a contract that motivates value increasing efforts by managers and induces risk-taking, will increase the likelihood of positive outcomes and eventually drive company performance and value over the long-term. We refer to these unique characteristics as the intangible features of SOBC schemes. A positive relationship, therefore, is expected between SOBC expense and shareholder returns.

Distressed companies tend to design compensation plans in a way that ties senior management wealth more closely to the market value of the companies; mainly through SOBC schemes (Gilson and Vetsuypens, 1993). These schemes are developed to encourage managers to take actions to recover losses and improve the performance of such companies over the long-term. Therefore, over the financial crisis, the above-mentioned intangible features of SOBC plans might become more accentuated from the investor's perspective, and indeed, more positively perceived as a value-increasing intangible asset. In addition, the recognised SOBC expense over the financial crisis whereby companies had suffered a reduction in their market value might also signal manager's optimism regarding the future prospects of a company, otherwise they might not accept SOBC schemes in their compensation packages. In line with this view, Schiemann and Guenther (2013) highlight the importance of the recognised cost of employees and their compensation packages in signalling profitable future activities, particularly in the case of loss years. Overall, it is reasonable to expect that the positive relationship between SOBC expense and shareholder returns is significantly higher during the financial crisis. 
On the other hand, investors are likely to place less valuation weight on accounting figures that reflect unrecognised assets for companies with deteriorating financial health (Barth et al., 1998), and/or during an economy-wide financial crisis (Davis-Friday et al., 2006). In addition, managers, particularly during the crisis, might be more opportunistic in exercising their discretion over the inputs used to estimate the associated expense of SOBC schemes (Aboody et al., 2006). ${ }^{5}$ This may have an offsetting impact on the positive relationship between the recognised SOBC expense and shareholder returns during the financial crisis. Overall, the above discussion suggests that the net effect of the crisis period on the relationship between the SOBC expense and shareholder returns remains an open empirical question that the current paper seeks to explore.

This paper also assesses the extent to which the relationship between SOBC expense and shareholder returns, during the financial crisis, varies with the level of ownership concentration by large shareholders. Previous studies show that sound corporate governance structure, ${ }^{6}$ such as ownership concentration by large shareholders, plays a key role in effectively monitoring and influencing the actions of managers, given that large shareholders have enough capital at stake and incentives to do so (e.g. Shleifer and Vishny, 1986; La Porta et al., 1998; Conyon and Florou, 2002). The percentage of shares held by large shareholders in each company is expected to influence the efficiency and the level of monitoring of SOBC schemes and prevent managers from engaging in opportunistic behaviour (using SOBC schemes and their associated expense)

\footnotetext{
${ }^{5}$ Although the IASB and the FASB do not prescribe a specific formula or model to be used for valuation of SOBC schemes, most companies prefer to use the Black-Scholes (BS) model since it is the easiest to implement in a company, particularly if a company lacks data or resources for a more accurate valuation (Landsberg, 2004). The Black-Scholes model calculates a theoretical call price (ignoring dividends paid during the life of the option) using the five key determinants of an option's price: the current market price of the share that underlies stock option at grant date, the exercise price of the option, the expected volatility of the share price, time to expiration, and short-term (risk-free) interest rate. Merton (1973) adjusted the BS model for dividends expected to be paid on the shares.

${ }^{6}$ In this paper, we consider firms with a high percentage of shares held by large shareholders as those with sound corporate governance structure.
} 
during the crisis at the expense of shareholders. That is, with more concentrated ownership, SOBC incentive packages are more likely to be tied with better performance (Sautner and Weber, 2015), and their associated expense is less likely to be subject to opportunistically managerial discretion. Yet the use of SOBC schemes might also be a potential self-serving tool for large influential shareholders, particularly during the financial crisis. Large shareholders become more inclined to exercise their power and might provide compensation schemes to the managers beyond what would be optimal for minority shareholders (Shivdasani and Yermack, 1999; Hanlon et al., 2003). This action aims to achieve private benefits at the expense of other shareholders, given the reduction in companies' performance and poor investment opportunities associated with the crisis period (Bae et al., 2012).

This paper focuses on a sample of financial institutions listed in the European Economic Area and Switzerland between 2005 and 2016 to examine the change in investors' perception of SOBC expense under IFRS2 in times of financial crisis. This is because, compared to companies in other sectors, European financial institutions were affected far more by both the global financial crisis that hit the European economies from 2007 and by the European sovereign debt crisis that engulfed the Eurozone from 2009. Hence, financial firms provide a powerful setting to test the effect of the crisis period on the valuation implications of accounting numbers. In addition, focusing on firms in a single industry provides a control for factors that affect firms differentially across industries and therefore reduces specification error (Christie, 1987).

Our paper's primary contributions to the literature are threefold. First, the paper contributes to the literature on the market valuation of SOBC expense (e.g. Rees and Stott, 2001; Aboody et al., 2004; Matolcsy et al., 2009). Prior studies focus on the relationship between SOBC expense and company market value/return mainly in largely tranquil periods; our paper is arguably the first to 
evaluate this relationship in times of financial crisis. Moreover, by focusing on the recognised SOBC expense, we add to the literature on the effect of the financial crisis on market valuation of financial statement information (e.g. Davis-Friday et al., 2006). Second, a large body of literature examined the power and incentives of shareholders with substantial shares/ownership to monitor the SOBC schemes' policy and protect shareholders against managerial opportunism (e.g. Shleifer and Vishny, 1997; Bae et al., 2012; Sautner and Weber, 2015). We add to this stream of literature by examining the role large shareholders play in explaining the variation in the association between SOBC and shareholders returns when companies' financial health deteriorates. Third, previous studies on the relationship between SOBC expense and company market value/return focus predominantly on the US context (e.g. Dechow et al., 1996; Rees and Stott, 2001; Espahbodi et al., 2002; Bell et al., 2002; Hanlon et al., 2003; Aboody et al., 2004; Landsman et al., 2006). ${ }^{7}$ Our paper extends prior literature by investigating the relationship in a non-US context. This responds to the call for additional studies on SOBC schemes in companies domiciled outside the US context (see Street and Cereola, 2004; Matolcsy et al., 2009; AlhajIsmail et al., 2018), and in the financial industry sector (see Mehran and Rosenberg, 2009). ${ }^{8}$

The remainder of the paper is organised as follows. The next section reviews prior research and develops our research hypotheses. The third section presents our research design and explains the data sources, sample composition and variables used. The empirical results are presented and discussed in the fourth section. Finally, the last section summarises our findings, draws

\footnotetext{
${ }^{7}$ In Europe we are aware of only one study by Bagna et al. (2010) who employ a sample of non-financial firms in Europe over the period of 2005-2006. Yet their research question is different from that studied in this paper, as they examine the value relevance of the Asset and Liability method to account for employee stock options.

${ }^{8}$ In addition to the sensitivity of using SOBC packages in financial firms given that these firms are more risk-oriented institutions and SOBC schemes tend to induce excessive risk-taking, the institutional environment and the practices for issuing SOBC packages are quite different in the European setting. Murphy (1999) reports that the overwhelming majority of share options issued in the US settings have their exercise price set at fair market value as their issue date, 10-year terms and no performance hurdles attached. In contrast, Europe offers a setting in which there is substantial variation in equity compensation because of the different legal, institutional and fiscal context and because the practice of issuing SOBC is more recent and less widespread (Mathieu, 2012).
} 
conclusions and inferences, identifies limitations of our study and suggests areas to be addressed in future research.

\section{Prior literature AND hyPOTheSis DeVElopMent}

\subsection{LITERATURE REVIEW}

\subsubsection{INFORMATION CONTENT OF SOBC EXPENSE}

The introduction of IFRS 2 (share-based payment) has radically changed the accounting treatment for SOBC schemes. Prior to $2005,{ }^{9}$ the cost of SOBC schemes was overwhelmingly disclosed in the footnotes but not recognised in the financial statements of companies. The view adopted by the International Accounting Standard Board (IASB) that all SOBC transactions ultimately lead to expense recognition, calculated based on the fair-value approach, came after an intensively controversial and prolonged debate on the accounting treatment of SOBC schemes (See Ratliff, 2005; Apostolou and Crumbley, 2005; Guay et al., 2003). The financial reporting implications and economic consequences surrounding the accounting treatment of SOBC schemes have been a subject of extensive discussion in the accounting literature (e.g. Dechow et al., 1996; Botosan and Plumlee, 2001; Carlin and Ford, 2006; Choudhary et al., 2009; AlhajIsmail et al., 2018). Particular focus has been given to the information content of disclosed and/or recognised expense of SOBC schemes (e.g. Bell et al., 2002; Aboody et al., 2004; Niu and $\mathrm{Xu}, 2009$; Matolcsy et al., 2009). This stream of literature has specifically attempted to operationalise the standard-setters' qualitative characteristics of accounting information, relevance and reliability ${ }^{10}$ in order to assess the market's perception of SOBC expense under

\footnotetext{
${ }^{9}$ On 19 February 2004, the IASB released IFRS2 (share-based payment), which was first applied to accounting periods starting 1st January 2005. Similarly, the FASB released SFAS 123R (share-based payment) in December 2004, as one of the earlier accounting standards that have been closely converged with IFRS. SFAS $123 \mathrm{R}$ was first applied to accounting periods ending in 2006.

${ }^{10}$ Issued in 2010, the IASB framework does not specify reliability as one of the qualitative characteristics of useful financial information. However, the IASB has explained that its meaning is mainly now included in 'faithful representation' (IASB, 2010, paragraph BC3.24).
} 
alternative accounting treatments, particular those utilised by US companies (e.g. Rees and Stott, 2001; Bell et al., 2002; Hanlon et al., 2003; Aboody et al., 2004). The evidence provided by this line of research, however, is mixed.

For example, Bell et al. (2002) document a positive association between employee share option expense, as reported in the pro forma disclosure, and annual share returns. They conclude that using SOBC schemes results in an off-balance sheet asset/investment that is highly valued by the market. Yet they acknowledge that their findings had limited applicability because the selected sample was restricted only to profitable computer software companies in the US over the period of 1996-1998. Using a sample of 756 US companies listed in 1996, Rees and Stott (2001) also find a positive relationship between disclosed employee share option expense and annual share returns. Aboody et al. (2004) also support this finding using a sample of large, small and medium-sized US companies over the period of 1996-1998. Similar findings are also found using Australian (Brown and Yew, 2002) and Canadian (Niu and Xu, 2009) samples of listed companies over the periods of 2000 and 2003-2005, respectively. These findings suggest that investors perceived the disclosed fair-value of share option expense in the footnotes as a relevant and reliable information about a value-increasing intangible asset to the company. Niu and Xu (2009) add that the value relevance and reliability of SOBC expense to investors is enhanced after mandating the recognition regime of expensing SOBC using the fair value approach. Hanlon et al. (2003) also report a significant positive relationship between future operating earnings and the value of share options granted to the top five executives of a sample of US companies over the period 1992-2000. These findings indicate that the expected incentive effects of SOBC schemes offset their cost and that investors price recognised SOBC expense as a relevant and reliable information about a value-increasing intangible asset. 
However, conflicting evidence does exist. Aboody (1996), for example, find no relationship between recognised SOBC expense and company market value for a sample of US companies in 1988. This finding suggests that the recognition regime to the cost associated with SOBC schemes in the income statement would not improve the informativeness of companies' net income. One reason for this result could be that companies were already disclosing the dilutive effect of SOBC grants on the earning within the footnotes of the financial reports using the pro forma disclosure. The recognition approach would, therefore, neither significantly influence how market participants perceive the cost associated with SOBC grants, nor affect investor's perception of the incentives derived from these grants.

Li (2003) document a negative association between share price and both outstanding employee share options and expected share option expense for a sample of 1,113 companies over the period of 1996 to 2000. Chamberlain and Hsieh (1999) also report a significantly negative relationship between share price and fair-value of share option grants issued by a sample of US companies. Similarly, Core et al. (2002) provide evidence of the dilutive effects of employee share options. That is, under the disclosure approach, the negative association between SOBC expense and companies value indicate that investors assign higher weightings to the dilutive associated cost of SOBC versus their incentive effect; and, therefore, the costs related to SOBC schemes are perceived as an expense (rent extraction) ${ }^{11}$ rather than an intangible asset.

The extant literature, therefore, provides mixed evidence on the direction and the significance of the relationship between SOBC expense and share price/return. The absence of the clearly explicit pro forma disclosure for SOBC grants has been highlighted by studies conducted prior to the introduction of FAS123R/IFRS2 (Skinner, 1996). This might be one reason for such

\footnotetext{
${ }^{11}$ The rent extraction view indicates that managerial power can lead to suboptimal compensation contracts that will, in turn, reduce shareholder wealth. Therefore, an alternate view of SOBC expense to the company could be that SOBC are the result of inefficient compensation schemes and rent extraction (Bebchuk et al., 2002).
} 
inconclusive results by earlier related studies conducted under the disclosure regime. Another possible reason for the negative association between the disclosed SOBC expense and shareholder return/ company market value in some previous studies could be that, unlike the recognised SOBC expense, the disclosed amount is less subject to the scrutiny of external auditors, which has an adverse impact on the reliability of such information and, in turn, on its association with market value/return. Matolcsy et al. (2009) add that the negative market valuation of SOBC expense would be obvious when SOBC schemes are granted primarily as a reward for past performance, while the positive market valuation would be dominant when SOBC schemes are used to provide incentives for enhanced future performance. Aboody et al. (2004) highlight that the direction, the magnitude, and the significance of the reported relationship between SOBC expense and company value after the mandatorily adoption of IFRS2/FAS123R is still vague and needs additional research.

\subsubsection{THE MARKET VALUATION OF ACCOUNTING INFORMATION DURING FINANCIAL CRISES}

Prior research has also investigated the impact of the economic environment on the market valuation of accounting information. For example, Graham et al. (2000) examine the incremental value relevance of equity book value and net income during the financial crisis in Asia in 1997. Based on a sample of companies listed in Thailand over the period of 1992-1998, their study shows that the incremental value relevance of the book value of equity increased while that of net income decreased after the crisis hit in Asia. Davis-Friday et al. (2006) also investigate the effect of the financial crisis in Asia, in 1997, on the value relevance of book value of equity and net income for a sample of companies listed in four countries: Indonesia, South Korea, Malaysia and Thailand. They document that the impact of the Asian crisis period on the value relevance of equity book value and net income varies across the countries. Further analysis shows that 
corporate governance factors at the country level influence the extent of changes in the value relevance of accounting numbers during the crisis in Asia.

Yet there is still scant evidence on how the market valuation of accounting information has changed around the recent global financial crisis and the European sovereign debt crisis. Based on a sample of companies listed in five European countries: Spain, Greece, Ireland, Italy, and Portugal over the period between 2008 and 2011, Kousenidis et al. (2013) find that the value relevance of reported earnings increased during the crisis. However, using the same sample over the period 2005 to 2011, Iatridis and Dimitras (2013) report mixed results across the countries on the effect of the crisis period on the combined value relevance of equity book value of equity and net income.

\subsubsection{OWNERSHIP CONCENTRATION}

One determinant of the market valuation of accounting information is corporate governance structure at company level. Corporate governance seeks to improve the quality of accounting information, reveal managerial efficiencies and reduce manipulation of earnings by management through the enforcement of appropriate standards (De Almeida et al., 2009). Ownership concentration by large shareholders is one of the common approaches to corporate governance throughout most of the world (e.g., Shleifer and Vishny, 1997). Research provides evidence that large shareholders tend to have incentives as well as power to effectively monitor and influence the actions of managers, given that they have enough capital at stake (e.g. Shleifer and Vishny, 1986; La Porta et al., 1998; Conyon and Florou, 2002). Bebchuk et al. (2010) point out that the opportunistic timing of SOBC grants awarded to Chief Executive Officers (CEOs) and Independent Directors between 1996 and 2005 is more widely observed in US companies with poor governance structures. Based on a sample of 1,914 US companies over the period of 1992- 
1997, Hartzell and Starks (2003) find that institutional ownership concentration serves as a monitoring role in mitigating the agency cost between shareholders and managers. They found that companies with more institutional investors have a higher level of pay for performance sensitivity. Using a sample of 81 large European companies in 2003, Sautner and Weber (2015) add that SOBC schemes that are favorable to CEOs and that have lower subsequent operating performance are those issued by companies with low ownership concentration.

Yet several previous studies find a negative impact of ownership concentration on the informativeness of earnings. Fan and Wong (2002), for example, report a negative association between the degree of ownership concentration and the coefficient from returns-earnings regression for a sample of 977 companies listed in seven East Asian countries between 1991 and 1995. They explain this result by the potential conflict of interest between large controlling shareholders and other investors, which might have a negative impact on the quality of accounting information. Similar findings are reported by Firth et al. (2007) for a sample of Chinese companies listed in the period 1998-2003. Our paper adds to the existing literature by examining the extent to which the stake of shares held by large shareholders, particularly over the crisis period, influences the association between shareholder return and mark-to-model fairvalue measurements that are inherently bound to measurement error and subject to significant managerial discretion.

\subsection{HYPOTHESES DEVELOPMENT}

\subsubsection{HYPOTHESIS 1}

The Agency theory uses the metaphor of a contract to describe the relationships between the principle and the agent. SOBC serves as one of the most efficient contracts that govern the 
relationship between the principal and the agent given the assumptions of self-interest behaviour, information asymmetry and risk-aversion. There are several intangible features associated to SOBC schemes. One of the main roles of SOBC schemes is to attract and retain highly-talented and skilled employees; the main driver of companies' intangible resources (Lev, 2001). This compensation mechanism is usually designed using targeted performance hurdles in order to align the interests of managers with those of shareholders and eventually drive a company's future performance and value over the long-term (Conyon and Sadler, 2003). Furthermore, it has been widely acknowledged that SOBC schemes create incentives to risk-averse managers to invest in high-risk projects that are likely to produce high-returns on behalf of risk-neutral shareholders (e.g., Jensen and Meckling, 1976; Murphy, 1999; Chen et al., 2006). From the managers' perspective, SOBC schemes represent an opportunity to increase their future share ownership, and hence wealth, if the performance hurdles attached to SOBC schemes are met. In line with the above view, investors are expected to perceive the associated expense of SOBC schemes as a value-increasing (intangible) asset that contributes to an improvement in the company's cash flows and value.

Indeed, a positive relationship between SOBC expense and company market value/share returns is widely reported in earlier related literature (e.g. Bell et al., 2002; Aboody et al., 2004; Niu and $\mathrm{Xu}, 2009)$. This positive relationship indicates that investors appreciate the intangible features of SOBC schemes and perceive their associated expense as a relevant and reliable information that is favourably reflected in share price (i.e. an intangible asset). Yet, the financial crisis is likely to have an impact on the valuation weight investors place on the intangible features of SOBC expense recognised by financial firms, which we aim to address in this paper. 
Over the financial crisis, the intangible features of SOBC contracts might become of increasing importance to investors for several reasons. Gilson and Vetsuypens (1993) point out that distressed companies tend to depend on SOBC schemes to compensate managers, as these schemes closely tie the latter wealth with shareholders' wealth. SOBC schemes are designed, in this case, to encourage managers to take actions in order to recover losses and improve the longterm performance and, in turn, the market value of issuance companies. From a managers' perspective, SOBC schemes represent an opportunity to increase their future wealth when they restore company performance and market value to pre-crisis levels and/or meet performance targets attached to SOBC schemes. Furthermore, the recognised SOBC expense over the financial crisis might signal a managers' optimism regarding the future prospects of a financial firm, otherwise they might not accept SOBC schemes in their compensation packages. This view suggests that SOBC can signal favourable insider's information on company value. Consistent with this view, Schiemann and Guenther (2013) highlight the importance of recognised cost of employees and their compensation packages in signalling profitable future activities, particularly in the case of loss years. Also, Yermack (1997) and Lam and Chng (2006) provide empirical evidence that the timing of SOBC grants coincides with favourable share price movements and insider buying activities, reflecting a sign of favourable information. Overall, it is reasonable to expect that intangible features attributable to SOBC expense might become more accentuated from the investors' perspective during the financial crisis; and indeed, more positively perceived as a value-increasing intangible asset.

The adverse effect of the financial crisis period on the relationship between SOBC expense and shareholder returns is also possible. One potential reason for such effect might be that over the crisis period, the probability of default increases. Hence, investors are more likely to place lower 
valuation weights on accounting numbers capturing the future growth opportunities (i.e. unrecognised assets) compared to that placed on the accounting figures that represent the liquidation value (Barth et al., 1998; Davis-Friday et al., 2006; Allen and Carletti, 2008). Another possible reason could be that the recognised expense of SOBC schemes is usually estimated using the 'mark to model' fair-value approach that is fundamentally subject to management discretions and estimation errors (Aboody et al., 2006; Johnston, 2006), particularly during the crisis period (Liao et al., 2013). For example, over the period of crises, managers might exploit the room given to them under IFRS 2 to exercise their discretion, mainly in the valuation assumptions used, to engage in 'big bath' accounting. "The aim of such behaviour is to influence contractual outcomes that depend on reported accounting numbers" (Healy and Wahlen, 1999: 368), or even to mislead some stakeholders about the underlying economic positions and performance of the company over the financial crisis. That is, the overall magnitude of the positive relationship between the recognised expense of SOBC schemes and shareholder returns would therefore be lessened. ${ }^{12}$

Market participants are mainly concerned with predicting future pay-offs; and weigh each signal they receive about a company depending on how much of the uncertainty about the company's future profits it resolves (Paul, 1992). SOBC schemes, as part of employee pay packages, play a key role in motivating managers to improve a company's future performance and signalling a managers' optimism regarding the company's prospects. That is, SOBC schemes could be a channel through which investors may infer insider's private information about companies' future financial prospects. This is particularly applicable when companies' financial heath deteriorates (Gilson and Vetsuypens, 1993; Schiemann and Guenther, 2013). Therefore, in times of financial

\footnotetext{
${ }^{12}$ This paper examines the net change in the relationship between SOBC expense and shareholder returns when the crisis hits rather than the different channels through which the crisis period affects this relationship.
} 
crisis, we expect investors to place more importance on the intangible features of SOBC and the related signalled optimism, compared with the offsetting impact of management discretions and estimation errors associated with SOBC expense.

Based on this context, we predict the positive association between SOBC expense and shareholder returns to be more accentuated over the crisis period. Therefore, our first research hypothesis is formulated in the alternative form as follows:

H1: The positive association between SOBC expense and shareholder returns is more pronounced during the financial crisis period than during the non-crisis period.

\subsubsection{HYPOTHESIS 2}

Financial institutions, particularly banks, tend to suffer from greater information asymmetry problems and have more opaque financial statements than non-financial companies, which tend to increase during a financial crisis (Beatty and Liao, 2014). Sound governance mechanisms, including designing effective SOBC schemes, are usually adopted by companies to address the information asymmetry problem and provide managers with efficient incentives to maximise shareholders' wealth.

In this context, ownership concentration by large shareholders is one of the main determinants of the strength of corporate governance (Shleifer and Vishny, 1997). Shareholders can also play a role in monitoring remuneration policy to increase the sensitivity of managers pay and company performance (Hartzell \& Starks, 2003; Clarkson et al., 2011). Previous studies show that large shareholders tend to have the incentives to effectively monitor managers and the power to force them to act in the best interest of shareholders, given that they have enough capital at stake. For example, Hartzell and Starks (2003) find that companies with more institutional investors have a 
higher level of pay for performance sensitivity. Sautner and Weber (2015) add that SOBC schemes that are favourable to CEOs and that have lower subsequent operating performance are those issued in companies with low ownership concentration.

The opportunistic recognition of SOBC expense by managers, (Aboody et al., 2006), is also likely to be more apparent during the financial crisis in order to overestimate/underestimate the reported results and/or mislead some stakeholders about the underlying economic conditions of the company. This opportunistic behaviour, however, is likely to be attenuated with more concentrated ownership by large shareholders who have the incentives as well as the power to effectively monitor the actions of managers (Shleifer and Vishny, 1986; La Porta et al., 1998; Conyon and Florou, 2002). Under such a scenario, accounting information is also more likely to better reflect the economic reality of a company. The market perception of SOBC schemes as a value-increasing intangible asset is therefore expected to be more pronounced with such a mechanism. That is, increasing ownership concentration, particularly over the crisis period, might lead to more value relevant mark-to-model fair-value measurements (herein SOBC expense), though they are inherently prone to measurement error and subject to significant managerial discretion (Liao et al., 2013).

It is worth mentioning that the use of SOBC schemes might also be a potential self-serving tool when ownership is concentrated, particularly during the financial crisis. For example, large controlling shareholders become more inclined to exercise their power to achieve private benefits at the expense of other shareholders, given the reduction in companies' performance and poor investment opportunities associated with the crisis period (Bae et al., 2012). In so doing, they can control the pay-setting process and provide compensation schemes to the managers beyond what would be optimal for minority shareholders (Shivdasani and Yermack, 1999; Hanlon et al., 
2003). If other investors anticipate this behaviour, the level of ownership concentration in this scenario would have an adverse impact on the positive relationship between the recognised expense of SOBC schemes and shareholder returns over the crisis period.

Based on this context, our second research hypothesis is formulated, in the alternative form, as follows:

H2: The positive association between SOBC expense and shareholder returns is more pronounced for financial firms with more concentrated ownership during the financial crisis period.

\section{RESEARCH DESIGN AND SAMPLE SELECTION}

\subsection{RESEARCH DESIGN}

Based on the valuation model introduced by Ohlson $(1995)^{13}$ and following prior studies (e.g. Aboody et al., 2004; Niu and Xu, 2009; Schiemann and Guenther, 2013), our baseline model is stated as follows:

$$
R_{i t}=\alpha_{0}+\alpha_{1} N I_{i t}+\alpha_{2} \Delta N I_{i t}+\alpha_{3} S O B C_{i t}+e_{i t}
$$

where $R_{i t}$ is the annual shareholder return inclusive of dividends for firm $i$ and measured as the 12-month return ending three months after the end of the fiscal year $t . N I_{i t}$ is the net income before the recognised SOBC expense for firm $i$ over the fiscal year $t$ and divided by the market value of equity at the beginning of year $t$, and $\Delta N I_{i t}$ is the change in $N I_{i t}$ between year $t$ and $t-1$. $S O B C_{i t}$ refers to the recognised SOBC expense of firm $i$ over the year $t$ divided by market value of equity at the beginning of year $t$. The coefficient $\alpha_{3}$ captures the relationship between SOBC

\footnotetext{
${ }^{13}$ The empirical implementation of the Ohlson model (1995) is "the price specification" in which the market value of equity is expressed as a function of equity book value, net income and the error term. Taking the first difference of the variables in both sides of "the price specification" would yield a model called "the return specification" in which share return is expressed as a function of net income, change in net income and the error term. "The return specification" addresses the econometric concerns raised about heteroskedasticity and scale bias in "the price specification" (Kothari and Zimmerman, 1995).
} 
expense and shareholder returns. ${ }^{14} \mathrm{~A}$ significant positive coefficient indicates that investors perceive SOBC expense as an unrecognised intangible asset, whereas a significant negative coefficient indicates that SOBC expense is perceived as a rent extraction.

In the first hypothesis, we test the changes in the relationship between SOBC expense and shareholder returns during the financial crisis. A dummy variable for the financial crisis therefore interacts with the recognised SOBC expense as follows:

$$
R_{i t}=\alpha_{0}+\alpha_{1} N I_{i t}+\alpha_{2} \Delta N I_{i t}+\alpha_{3} S O B C_{i t}+\alpha_{4} C R I S I S+\alpha_{5} C R I S I S * S O B C_{i t}+e_{i t}
$$

where CRISIS is a dummy variable coded 1 for the years of the crisis period (2007-2011) and 0 otherwise, as the non-crisis period (2005-2006 \& 2012-2016). The coefficient $\alpha_{5}$ reflects the change in how investors perceive the recognised expense of SOBC schemes when the financial crisis hits the economies of the countries under investigation. If investors place a higher valuation weight on the intangible features of SOBC expense during the financial crisis, then $\alpha_{5}$ will be significant and positive.

In the second hypothesis, we test the change in how investors perceive the recognised expense of SOBC schemes during the crisis as a function of the percentage of shares held by large shareholders - a proxy for ownership concentration. This results in the following model:

$$
\begin{gathered}
R_{i t}=\alpha_{0}+\alpha_{1} N_{i t}+\alpha_{2} \Delta \text { NI }_{i t}+\alpha_{3} \text { SOBC }_{i t}+\alpha_{4} \text { CRISIS }+\alpha_{5} \text { Large }_{i t}+\alpha_{6} \text { CRISIS } \\
\quad * S O B C_{i t}+\alpha_{7} \text { Large }_{i t} * S O B C_{i t}++\alpha_{8} \text { Large }_{i t} * \text { CRISIS } \\
+\alpha_{9} \text { Large } * \text { CRISIS } * S O B C_{i t}+e_{i t}
\end{gathered}
$$

\footnotetext{
${ }^{14}$ Endogeneity is a common issue in studies that address the market valuation of SOBC expense. This issue is less likely to be problematic in our setting because our hypotheses are concerned with how the association between SOBC expense and shareholder returns changes during the financial crises, which is largely an exogenous macroeconomic shock, and how this association changes with the comparative power of shareholders within the corporate governance structure of each financial firm. That is, our results are less likely to be subject to the endogenous determination of SOBC expense and shareholder returns.
} 
Large is the percentage of shares held by large shareholders (those hold 5\% or more of the ordinary shares) for firm $i$ at the end of year $t$. If the proportion of shares held by large shareholders has a positive impact on the association between SOBC expense and shareholder returns during the financial crisis, the coefficient $\alpha_{9}$ will be significant and positive.

\subsection{SAMPLE AND DATA}

Taking advantage of the IFRS 2 adoption, we hand-collected SOBC expense in the years 2005 through 2016 and the proportion of shares held by large shareholders from the published annual reports and/or corporate governance reports of 63 financial firms (717 firm-year observations). ${ }^{15}$ The BankScope database is used to identify financial firms that 1) publish their consolidated financial statements under IFRS and 2) are domiciled and listed in one of the markets in the European Economic Area (EEA) and Switzerland over the crisis period (2007-2011) and at least in one year in the non-crisis period (i.e. either 2006 or 2012). ${ }^{16}$ This procedure produced an initial sample of 183 financial institutions. We first excluded 22 firms with missing market and/or accounting data necessary to run our regressions. We then excluded 18 firms with unavailable annual reports and a further 18 firms as their annual report were unavailable in English on the firm's website or via Thomson One Banker. Finally, a further 62 financial institutions were excluded from our sample as they did not use SOBC schemes. The distribution of our observations of financial firms across countries is shown in table 1.

<Insert table 1 here>

\footnotetext{
${ }^{15}$ Our sample is imbalanced over the study period due to data unavailability in some years.

${ }^{16}$ We use this criterion in order to capture the impact of the financial crisis on the changes in the relationship between SOBC expense and shareholder returns.
} 
The UK has the largest number of financial firms included in our sample (15 financial firms). At the other extreme, only one financial firm in our sample (which is a bank) is listed in each of the following countries: Hungry, Ireland, Malta and Portugal.

\section{DESCRIPTIVE STATISTICS AND EMPIRICAL RESULTS}

\subsection{DESCRIPTIVE STATISTICS}

Table 2 (panel A) identifies the descriptive characteristics of the selected sample of financial firms over the period of 2005-2016. It shows that over this period, the sample financial firms, on average, recognised $€ 87.27$ million of SOBC expense. The mean (median) of annual share returns inclusive of dividends $[R]$, and the mean (median) of the net income before the recognised SOBC expense and scaled by market value of equity at the begining of the year $[N I$, are $0.15(0.09)$ and $0.06(0.08)$, respectively, for the whole study period. Finaly, the average percentage of shares held by large shareholders is $41.1 \%$ in at least $50 \%$ of our sample.

Interestingly, table 2 (panel B) shows that the average of SOBC expense increased from $€ 65.17$ million in the pre-crisis period to $€ 88.39$ million over the crisis period and then increased again to $€ 94.89$ million in the post-crisis period. In other terms, on average, there is an increase in the absolute SOBC expense recognised by financial firms over the study period. Table 2 (panel B) also shows, as one would expect, both the mean and the median of annual share returns are lower over the crisis period in comparsion to both the pre-crisis (2005-2006) and post-crisis (20122016) periods. The mean (median) of the net income excluding SOBC expense and scaled by market value of equity at the beginning of the year also dropped down from $0.119(0.105)$ during the pre-crisis period to 0.059 (0.073) during the crisis period and then slightly went down to 
$0.048(0.072)$ in the post crisis period. The correlations among main variables used in our models are reported in table 2 (panel C).

\section{<Insert table 2 here>}

As expected, the correlation matrix shows that the annual share returns are significantly positively correlated with annual earnings and SOBC expense. This correlation is consistent with a positive mechanical relation between SOBC expense and share returns. ${ }^{17}$

\subsection{EMPIRICAL RESULTS}

Table 3 (Panel A) presents the regression results of our baseline model, equation (1), which tests the relationship between share returns and SOBC expense for the full sample period, 2005-2016. As expected, the coefficient on the net income before the recognised SOBC expense is positive and statstically signifnant at the $1 \%$ level. It also shows that share returns are negatively and significantly associated with change in net income. ${ }^{18}$ Table 3 (Panel A) also shows that there is a significant positive relationship between SOBC expense and shareholder returns over the whole sample period. This significant positive relationship suggests that investors perceive the recognised expense of SOBC schemes as a relevant and reliable information that reflects a valueincreasing intangible asset to the firm. This evidence, using a sample of EU financial firms, is in line with that of previous studies conducted in the US context (e.g. Rees and Stott, 2001; Bell et al., 2002; Brown and Yew, 2002; Hanlon et al., 2003; Aboody et al., 2004).

<Insert table 3 here>

\footnotetext{
${ }^{17}$ The multicollinearity is tested using the variance inflation factor (VIF) and tolerances for the main regressions run in this paper. The VIF and tolerance value (not reported) confirm that there are no serious concerns about multicollinearity in our model.

${ }^{18}$ Surprisingly, the coefficient on the change in net income before recognised SOBC expense is negative and statistically significant. Some prior studies that use samples of European companies over periods included in this study also reported a negative association between share return and change in net income (e.g. Tsalavoutas et al., 2012 in Greece; Kousenidis et al. 2013 in five European countries).
} 
Table 3 (Panel B) presents the results on the impact of the financial crisis on the relationship between SOBC expense and shareholder returns. The model employed in Panel B allows the coefficient on SOBC expense to vary between the non-crisis period (2005-2006 \& 2012-2016) and the financial crisis period (2007-2011). The coefficient on SOBC expense over the non-crisis period is positive and statistically significant. This evidence again is consistent with that of previous studies (e.g. Rees and Stott 2001; Bell et al., 2002) that suggest investors favourably appreciate the intangible features of SOBC schemes in the non-crisis period.

More importantly, table 3 (Panel B), shows that the coefficient on the interaction term $\alpha_{5}$ $\left[C R I S I S{ }^{*} S O B C\right]$ is positive and significant at the $1 \%$ level. This result confirms our first hypothesis and indicates that the intangible value attributable to the recognised expense of SOBC schemes, as a value-increasing asset, is significantly more accentuated in the financial crisis period relative to the non-crisis period. Investors seems to appreciate the intangible features attributable to the recognised expense of SOBC schemes more during the financial crisis period relative to the non-crisis period. Particularly, the ability of SOBC schemes to motivate value increasing efforts by managers and signalling the latter's optimism regarding the future prospects of a firm appears to result in an increase in the positive association between SOBC expense and shareholder return during the crisis period.

Table 3 (Panel C) presents the regression results of equation (3) that tests the change in the relationship between SOBC expense and shareholder returns during the financial crisis as a function of the percentage of shares held by large shareholders, our proxy to ownership concentration. Table 3 (Panel C) shows that in the non-crisis period, the coefficient on SOBC expense recognised by financial firms that have the lowest percentage of shares held by large shareholders, $\alpha_{3}$, is positive, yet insignificant. Possible reasons for this result are the 
opportunistic timing of SOBC grants (Bebchuk et al., 2010) and the tendency of management to opportunistically estimate SOBC expense (Aboody et al., 2006) in firms with poor governance structure. Consistently, Sautner and Weber (2015) find evidence that SOBC schemes that are favourable to CEOs and that have lower subsequent operating performance are those issued in companies with low ownership concentration.

The coefficient on the interaction term, $\alpha_{6}[C R I S I S * S O B C]$, in table 3 (Panel C) is positive, yet, statistically insignificant. This result suggests that the relationship between SOBC expense and shareholder returns seems to be unaltered over the financial crisis for financial firms that have the lowest percentage of shares held by large shareholders. As indicated above, this may due to the weak relationship between SOBC expense and shareholder returns over the non-crisis period for such firms.

More importantly, and as predicted by our second hypothesis, Table 3 (Panel C) shows that the coefficient on the three-way interaction term, $\alpha_{9}\left[\operatorname{Large}^{*} C R I S I S * S O B C\right]$, is positive and significant [at the $1 \%$ level]. This result indicates that over the crisis period SOBC expense, recognised by financial firms with a higher percentage of shares held by large shareholders, seem to be more positively associated with shareholder returns. That is, the association between SOBC expense and shareholder returns during the crisis period increases with a corporate governance structure characterised by more ownership concentration. Ownership concentration by large shareholders in financial firms, particularly during the financial crisis, seems to contribute to the efficient design and closely monitoring of SOBC schemes whose associated expense is perceived by investors as a value-increasing intangible asset. This finding is in line with those of Hartzell and Starks (2003) and Sautner and Weber (2015) who find that companies with more ownership concentration design effective compensation packages that drive their financial performance. 
Our findings support the notion that large shareholders have the incentives to monitor the performance of management as well as the voting power to force management to act in the interest of shareholders (Shleifer and Vishny, 1986; La Porta et al., 1998; Conyon and Florou, 2002). The significant positive sign on the three-way interaction term suggests that ownership concentration by large shareholders mitigates the potential opportunistic behaviour associated with the recognition of SOBC expense during the crisis period.

\subsection{ADDITIONAL ANALYSIS AND ROBUSTNESS}

The non-crisis period includes the first two years after the mandatory adoption of IFRS 2 (i.e. $2005 \& 2006)$ for many financial firms in our sample. The relationship between SOBC expense and shareholder returns might be affected by firms and capital markets first experience with this standard, which in turn could have an impact on our results when we evaluate the changes in the relationship as a result of the crisis. ${ }^{19}$ To address this issue, we run the regression in equation (1) separately for the three distinctive periods: the pre-crisis period of 2005-2006, the crisis period of 2007-2011, and the post-crisis period of 2012-2016.

<Insert table 4 here>

As shown in Table 4 (Panel A), the estimated coefficient on SOBC expense in the pre-crisis period is negative and statistically insignificant. This result may be due to the reliability concerns associated with SOBC expense, particularly in the first few years of the mandatory adoption of IFRS2, which results in a reduction in the valuation weight investors placed on SOBC expense. Interestingly, Choudhary et al. (2009) provide evidence that companies accelerated the vesting condition of SOBC grants to avoid recognising expenses for standing unvested grants using the

\footnotetext{
${ }^{19} \mathrm{We}$ are grateful to an anonymous reviewer for raising this point and providing helpful suggestions to address it.
} 
fair-value approach in the first-year adoption in their financial reporting. ${ }^{20}$ Table 4 also shows that the coefficient on SOBC expense, $\alpha_{3}$, increases from $(-3.51)$ in the pre-crisis period to (19.47) in the crisis period and this increase in the estimated coefficient (22.983) is statistically significant. Table 4 also shows that the estimated coefficient on SOBC expense in the crisis period (19.47) is higher in magnitude than that in the post-crisis period (5.916), and the difference (13.554) is statistically significant. This confirms our finding that the positive relationship between SOBC expense and share returns is more pronounced during the crisis period relative to non-crisis period, including both pre-crisis and post-crisis periods.

In addition, the crisis period in this study (2007-2011) comprises the global financial crisis that hit the European economies from 2007 and by the European sovereign debt crisis that engulfed the Eurozone from 2009. We, therefore, divided the study period into two sub-periods. The first sub-period is $2005-2008$ to address the change in the association between SOBC expense and shareholder returns as a result of the global financial crisis of 2007-2008 (i.e. the coefficient of SOBC expense is allowed to vary between the pre-crisis period and the financial crisis period). The second sub-period is 2009-2016 to address the corresponding change in this relationship as a result of the sovereign debt crisis of 2009-2011 (i.e. the coefficient of SOBC expense is allowed to vary between the sovereign debt crisis period and post-crisis period).

<Insert table 5 here>

Table 5 (Panel A) contains the results of running the regression in equation (2) over the period 2005-2008. The estimated coefficients on $S O B C$ in the pre-crisis period (2005-2006) is statistically insignificant while that on the interaction between CRISIS and SOBC is positive and

\footnotetext{
${ }^{20}$ The fair value of all share option schemes awarded after November 2002, with first vesting after 1 January 2005 were required under IFRS2 to be included in the charge to profits.
} 
statistically significant. This evidence again confirms our main finding that there is an increase in the association between SOBC expense and shareholder returns in the global financial crisis period. Table 5 (Panel B) presents the results of estimating the regression model in equation (2) over the period 2009-2016. The coefficient on SOBC expense during the post-crisis period is positive and statistically significant. More importantly, the estimated coefficient on the interaction term between CRISIS and SOBC is positive and statistically significant only at the $10 \%$ level. This result suggests that the association between SOBC expense and shareholder returns is marginally higher in the European sovereign debt crisis (2009-2011) period relative to the post-crisis period (2012-2016). A potential reason for this marginal difference is that our sample includes firms that might be less affected by the sovereign debt crisis, especially those domiciled out of the Eurozone. ${ }^{21}$ To investigate this issue more, we re-run the main regression in equation (2) for the period between 2009-2016 and for the firms domiciled in the Eurozone only (i.e. for firms hit the most by the sovereign debt crisis in Europe). Table 5 (Panel C) shows that the coefficient on CRISIS and SOBC is positive and statistically significant (at the $1 \%$ level), suggesting that the association between SOBC expense and shareholder returns is more pronounced in the crisis period in comparison to the post-crisis period.

Additionally, we also rerun the regression in equation (2) for the full sample period excluding the 2007-2008 financial crisis and then excluding the 2009-2011 period. Our untabulated results hold in both cases. We also test the association between SOBC expense and shareholder returns over two periods: 2007-2008 and 2009-2011. Untabulated results show that the difference in the estimated coefficients on SOBC between the two crises periods: 2007-2008 \& 2009-2011 is

\footnotetext{
${ }^{21}$ To ensure that our results are not driven by the financial firms in the Eurozone only, we re-estimate the main regressions in this paper using a dummy variable for these firms and our results hold.
} 
statistically insignificant. Overall, the additional analyses suggest that our results hold using alternative sub-periods of the crisis.

This study considers the period (2007-2011) as the crisis period. There is no consensus in the literature on the beginning and end of the global financial crisis and sovereign debt crisis. For instance, some previous studies mark 2007 as the beginning of the crisis period (e.g. Beltratti and Stulz, 2012; Cohen et al., 2011), while others consider 2008 as the first year in which the impact of the crisis became globally evident (e.g. Morris et al., 2016). As a sensitivity test, untabulated results confirm the findings in this paper after removing the year 2007 and/or 2011 (i.e. the cutoff years) from the sample.

As a further analysis, we also repeat our analyses using a subsample of banks to test whether our reported results are also valid in the banking industry. Banks ${ }^{22}$ differ from other financial institutions in that their activities include mainly deposit-taking and loan-making, and banks are subject to regularity capital requirements. Untabulated results confirm that our findings hold for the sub-sample of banks.

We further investigate whether our results are robust after controlling for various firms' characteristics that potentially affect the changes in the relationship between the recognised expense of SOBC schemes and shareholder returns when the financial crisis hit. Table 6 presents the results of running the main regression in equation (2) after partitioning our sample based on the following firms' characteristics: firm size (firms are classified as either small or large firms using the median value of average total assets over the study period), and firm potential growth

\footnotetext{
${ }^{22}$ We use the classification of Bankscope to identify the sub-sample of banks and then we exclude banks with average net loan to total assets smaller than $10 \%$ over the study period.
} 
rate (firms are classified as either low or high growth firms using the median value of average yearly market to book value ratio over the study period).

<Insert table 6 here>

As shown in table 6, our results continue to be similar to those reported in table 3 . Thus, our conclusion on the changes in association between SOBC expense and shareholder returns when the financial crisis hit does not change after controlling for firm size and potential growth opportunity.

In addition, as a sensitivity analysis, we run the main regressions in equation (2) \& (3) in this study after replacing the dependent variable with the 12-month return ending at the end of the fiscal year as well as ending the six months after the end of the fiscal year. Untabulated results largely support our main reported findings in this paper. Furthermore, in this study, the panel of firms comprises of a large number of firms in comparison to a relatively small number of years, which raises concerns about potential cross-sectional dependence in the data (Pesaran, 2006). Therefore, as a further robustness check and as suggested by Pesaran (2006), we re-estimate the main regression that examines the effect of the financial crisis period on the relationship between SOBC expense and shareholder returns by including the cross-sectional means of both dependent and independent variables. Untabuated results confirm that our main finding remains substantially unaltered.

Finally, as a robustness test, we control for potential self-selection bias in the results, as the firms in our sample voluntarily issue SOBC schemes and therefore may not represent a random selection of European financial firms. We run the two-stage regression procedure suggested by Heckman (1979) on equations (1, 2 \& 3). In the first stage, we model our sample firms' decision 
to use SOBC schemes. Following prior studies, such as Core and Guay (2001); John and John (1993) and Alhaj-Ismail et al. (2018), we predict that the decision to use SOBC schemes is a function of the following factors: (i) firm size, measured by the lagged total assets, (ii) firm leverage, measured by firm's total debt divided by shareholders equity, (iii) firm opportunity growth, measured by the lagged market to book value ratio, (iv) legal traditions under which a financial firm operates, included as a dummy variable equal to 1 if the financial institution is domiciled in a common-law country and 0 if it is domiciled in a code-law country. In the second stage we include the Inverse Mills Ratio from the first stage as an additional explanatory variable in our main regressions (i.e. equations 1,2 \& 3).

<Insert table 7 here>

Table 7 shows the results reported in table 3 are generally robust to this estimation method. Consequently, the total net effect of the financial crisis on the association between SOBC expense and shareholder returns remains positive. The positive relationship between SOBC expense and shareholder returns during the crisis is also more pronounced for financial firms with more concentrated ownership.

\section{CONCLUDING REMARKS AND IMPLICATIONS}

This study adds to the literature on the market valuation of SOBC expense (e.g. Rees and Stott, 2001; Aboody et al., 2004; Matolcsy et al., 2009) and to the literature on the effect of financial crises on the market valuation of accounting information (e.g. Davis-Friday et al., 2006; Choi et al., 2011; Kousenidis et al., 2013). It utilises a sample of financial firms listed in the European Economic Area (EEA) and Switzerland between 2005 and 2016 to make inferences about the effect of the financial crisis on the relationship between the recognised expense of SOBC 
schemes and shareholder returns. The study also assesses whether the relationship between SOBC expense and shareholder returns during the financial crisis varies with the level of ownership concentration by large shareholders.

The results suggest that the relationship between shareholder returns and the recognised expense of SOBC expense over the entire sample period is significantly positive, indicating that investors perceive the latter as a value-increasing intangible asset. The intangible features of this asset are represented in the ability of SOBC contracts to attract and retain highly talented employees, motivate higher efforts and increase the level of risk-taking by managers in a way that contributes towards increasing firms' performance and value. This finding is consistent with those of a large body of empirical research on the relationship between company market value/return and SOBC expense recognised by US companies (Rees and Stott, 2001; Brown and Yew, 2002; Hanlon et al., 2003; Aboody at el., 2004). More importantly, we find evidence that the positive relationship between the recognised expense of SOBC schemes and shareholder returns is significantly more apparent over the financial crisis. This finding suggests that investors place more emphasis on the unrecognised intangible features of SOBC contracts during the crisis even though their associated expenses are subject to managerial discretions and measurement errors. In line with Schiemann and Guenther's (2013) results, our findings also highlight the increasing importance of the recognised expense of SOBC schemes in motivating a value-increasing effort by managers to recover losses as well as in signalling managers' optimism regarding the future prospects of companies in times of financial crisis.

Finally, the positive relationship between the recognised expense of SOBC schemes and shareholder returns over the financial crisis is also more apparent for financial firms with more concentrated ownership, measured by the percentage of shares held by large shareholders. This 
finding emphasises the power and incentives of shareholders with substantial shares/ownership to monitor the SOBC schemes' policy and protect shareholders against managerial opportunism (Shleifer and Vishny, 1997; Bae et al., 2012; Sautner and Weber, 2015), especially when firms' financial health deteriorates. The higher the level of ownership concentration, the more likely SOBC incentive packages are to be tied with better performance and their associated expenses to be less subject to opportunistically managerial discretion.

Findings of this paper have implications for financial reporting regulators and users. Firstly, the results support the IASB and FASB's decision on mandating IFRS2/FAS123R that favours enhanced transparency, value relevance, comparability and consistency over the costs associated with SOBC schemes. The results can also be of interest to accounting standard-setters and security commissions who wish to better understand the valuation consequences of SOBC expense during the financial crisis. Finally, our results have implications for academic and professional users who are interested in motivational aspects of SOBC schemes and related corporate governance issues. Indeed, ownership concentration by large shareholders, particularly over the crisis period, makes mark-to-model fair-value measurements more associated with company value even though they are inherently prone to measurement error and subject to significant managerial discretion. The overall result supports the notion that reliability is about faithful representation, not precision.

This work offers some avenues for further research. Other countries adopted IFRS2 or its equivalent FAS123R. Future research, therefore, can be conducted in this area, and uses a wider data set from different sectors and more countries, particularly emerging economies. Secondly, we use only one factor to proxy for corporate governance (i.e. the level of ownership 
concentration by large shareholders). Future research could extend the analysis in this paper by using a broader set of corporate governance factors. 


\section{REFERENCES}

Aboody, D., 1996. Market valuation of employee stock options. Journal of Accounting and Economics, 22(1-3), 357-391. https://doi.org/10.1016/S0165-4101(96)00439-9.

Aboody, D., Barth M., Kasznik, R., 2006. Do firms manage stock-based compensation expense disclosed under SFAS 123? Review of Accounting Studies, 11(4), 429-461. https://doi.org/10.1007/s11142-006-9013-0.

Aboody, D., Barth, M., Kasznik, R., 2004. SFAS No. 123 stock-based compensation expense and equity market values. The Accounting Review, 79(2), 251-275. https://doi.org/10.2308/accr.2004.79.2.251.

Alhaj Ismail, A., Adwan, S. and Stittle, J., 2018. Does accounting treatment of share-based payments impact performance measures for banks? Australian Accounting Review, (forthcoming). https://doi.org/10.1111/auar.12247.

Allen, F., Carletti, E., 2008. Mark-to-market accounting and liquidity pricing. Journal of Accounting and Economics, 45(2), 358-378. https://doi.org/10.1016/j.jacceco.2007.02.005.

Apostolou, N. G., Crumbley, D. L., 2005. Accounting for stock options: Update on the continuing conflict. The CPA Journal, 75(8), 30-33.

Bae, K.-H., Baek, J.-S., Kang, J.-K., Liu, W.-L., 2012. Do controlling shareholders' expropriation incentives imply a link between corporate governance and firm value? Theory and evidence. Journal of Financial Economics, 105(2), 412-435. https://doi.org/10.1016/j.jfineco.2012.02.007.

Bagna, E., Bini M., Bird, R., Francesco M., Reggiani. F., 2010. Accounting for employee stock options: what can we learn from the market's perceptions? Journal of International Financial Management and Accounting, 21(2), 161-186. https://doi.org/10.1111/j.1467646X.2010.01039.x.

Barth, M. E., Beaver, W. H., Landsman, W. R., 1998. Relative valuation roles of equity book value and net income as a function of financial health. Journal of Accounting and Economics. 25(1), 1-34. https://doi.org/10.1016/S0165-4101(98)00017-2.

Beatty, A., Liao, S., 2014. Financial accounting in the banking industry: A review of the empirical literature. Journal of Accounting and Economic, 58(2), 339-383. https://doi.org/10.1016/j.jacceco.2014.08.009.

Bebchuk, L. A., Grinstein, Y., Peyer, U., 2010. Lucky CEOs and lucky directors. The Journal of Finance, 65(6), 2363-2401. https://doi.org/10.1111/j.1540-6261.2010.01618.x. 
Bebchuk, L.A., Jesse M. F., Walker, D.I., 2002. Managerial power and rent extraction in the design of executive compensation. University of Chicago Law Review 69, 751-846. (DOI): $10.3386 / \mathrm{w} 9068$.

Bell, T.B., Landsman, W.R., Miller, B.L., Yeh, S., 2002. The valuation implications of employee stock option accounting for profitable computer software firms. The Accounting Review, 77(4), 971-996. https://doi.org/10.2308/accr.2002.77.4.971.

Beltratti, A., Stulz, R.M., 2012. The credit crisis around the globe: Why did some banks perform better? Journal of Financial Economics, 105(1), 1-17. https://doi.org/10.1016/j.jfineco.2011.12.005.

Botosan, C. A., Plumlee, M. A., 2001. Stock option expense: the sword of damocles revealed. Accounting Horizons, 15(4), 311-327. https://doi.org/10.2308/acch.2001.15.4.311.

Brown, P., Yew, E., 2002. How do investors regard ESOs? Australian Accounting Review, 12(1), 36-42. https://doi.org/10.1111/j.1835-2561.2002.tb00193.x.

Carlin, T.M. and Ford, G., 2006. Empirical evidence on the use, size and cost of executive options schemes in Australia, Research in International Business and Finance, 20 (3): 340-47. https://doi.org/10.1016/j.ribaf.2005.08.002.

Chamberlain, S., Hsieh, S., 1999. The Effectiveness of SFAS 123 employee option cost disclosures. Working paper, Santa Clara University.

Chen, C.R., Steiner, T.L., Whyte, A.M., 2006. Does stock option-based executive compensation induce risk-taking? An analysis of the banking industry. Journal of Banking and Finance, 30(1), 915-945. https://doi.org/10.1016/j.jbankfin.2005.06.004.

Choi, J.-H., Kim, J.-B., Lee, J. J., 2011. Value relevance of discretionary accruals in the Asian financial crisis of 1997-1998. Journal of Accounting and Public Policy, 30(2), 166-187. https://doi.org/10.1016/j.jaccpubpol.2010.09.002.

Choudhary, P., Rajgopal, S., Venkatachalam, M., 2009. Accelerated vesting of employee stock options in anticipation of FAS 123-R. Journal of Accounting Research, 47(1), 105-146. https://doi.org/10.1111/j.1475-679X.2008.00316.x.

Christie, A. A., 1987. On cross-sectional analysis in accounting research, Journal of Accounting and Economics, 9(3), 231-258. https://doi.org/10.1016/0165-4101(87)90007-3.

Clarkson P., Walker J., Nicholls S., 2011. Disclosure, shareholder oversight and the pay performance link. Journal of Contemporary Accounting and Economics 7(2), 47-64. https://doi.org/10.1016/j.jcae.2011.07.001. 
Cohen, L.J., Cornett, M.M., Marcus, A.J., Tehranian, H., 2014. Bank earnings management and tail risk during the financial crisis. Journal of Money, Credit and Banking, 46(1), 171-197. https://doi.org/10.1111/jmcb.12101.

Conyon, M. J., Florou, A., 2002. Top executive dismissal, ownership and corporate Performance. Accounting and Business Research, 32(4), 209-225. https://doi.org/10.1080/00014788.2002.9728971.

Conyon, M. J., Sadler, G. V., 2003. Executive pay, tournaments and corporate performance in UK firms. International Journal of Management Reviews, 3(2), 141-168. https://doi.org/10.1111/1468-2370.00060.

Core, J., Guay, W., 2001. Stock option plans for non-executive employees, Journal of Financial Economics, 61 (2):253-87. https://doi.org/10.1016/S0304-405X(01)00062-9.

Core, J., W. Guay., Kothari, S. P., 2002. The Economic dilution of employee stock option: diluted esp for valuation and financial reporting, The Accounting Review 77(3), 627-652. https://doi.org/10.2308/accr.2002.77.3.627.

Davis-Friday, P. Y., Eng, L. L., Liu, C.-S., 2006. The effects of the Asian crisis, corporate governance and accounting system on the valuation of book value and earnings. The International Journal of Accounting, 41(1), 22-40. https://doi.org/10.1016/j.intacc.2005.12.002.

De Almeida, J. E. F., Lopes, A. B., Toniato, J., Da Costa, F. M., 2006. Earnings management and industry classification in Brazil: An exploratory investigation, Corporate Ownership and Control, 3, 1, pp.144-149. http://doi.org/10.22495/cocv3i1c1p3.

Dechow, P., A. Hutton., Sloan, R., 1996. Economic consequences of accounting for stock-based compensation. Journal of Accounting Research, 34(Suppl.), 1-20. doi:10.2307/2491422.

Espahbodi, H., Espahbodi, P., Rezaee, Z., Tehranian, H., 2002. Stock price reaction and value relevance of recognition versus disclosure: the case of stock-based compensation. Journal of Accounting and Economics, 33(3). 343-373. https://doi.org/10.1016/S0165-4101(02)00048-4.

Fan, J.P., Wong T.J., 2002. Corporate ownership structure and the informativeness of accounting earnings in East Asia. Journal of Accounting and Economics, 33(3), 401-425. https://doi.org/10.1016/S0165-4101(02)00047-2.

Financial Accounting Standards Board (FASB) 2004, Statement of Financial Accounting Standard No. 123: Revised, Share-based Payments, FASB, Norwalk, Connecticut.

Firth M, P. Fung, Rui. O., 2007. How ownership and corporate governance influence chief executive pay in China's listed firms. Journal of Business Research, 60(7), 776-795. https://doi.org/10.1016/j.jbusres.2007.01.014. 
Gilson, S. C., M. R. Vetsuypens, 1993. CEO compensation in financially distressed firms - an empirical-analysis. Journal of Finance 48(2), 425-458. https://doi.org/10.1111/j.15406261.1993.tb04722.x.

Graham, R., King, R., Bailes, J., 2000. The value relevance of accounting information during a financial crisis: Thailand and the 1997 decline in the value of the baht. Journal of International Financial Management and Accounting, 11(2), 84-107. https://doi.org/10.1111/1467646X.00057.

Guay, W. R., Kothari, S. P., Sloan, R. G., 2003. Accounting for employee stock options. American Economic Review, 93(2), 405-409. DOI: 10.1257/000282803321947425.

Hall, B. J., Murphy, K, J., 2002. Stock Options for Undiversified Executives. Journal of Accounting and Economics. 33 (1), 3-42. https://doi.org/10.1016/S0165-4101(01)00050-7.

Hanlon, M., Rajgopal S., Shevlin, T., 2003. Are executive stock options associated with future earnings? Journal of Accounting and Economics, 36(1-3), 3-43. https://doi.org/10.1016/j.jacceco.2003.10.008.

Hartzell, J. C., Starks, L. T., 2003. Institutional investors and executive compensation. The journal of finance, 58(6), 2351-2374. https://doi.org/10.1046/j.1540-6261.2003.00608.x.

Healy, P. M., Wahlen, J. M. 1999. A review of the earnings management literature and its implications for standard setting. Accounting Horizons, 13(4), 365-383. https://doi.org/10.2308/acch.1999.13.4.365.

Iatridis, G., Dimitras, A. I., 2013. Financial crisis and accounting quality: Evidence from five European countries. Advances in Accounting, 29(1), 154-160. https://doi.org/10.1016/j.adiac.2013.03.001.

International Accounting Standards Board., 2004. International financial reporting standard No. 2, share based payment. London: International Accounting Standards Board.

International Accounting Standards Board., 2010. The Conceptual Framework for Financial Reporting. London: International Accounting Standards Board.

Jensen, M., Meckling, W., 1976. The Theory of the firm: Managerial behavior, agency costs and ownership structure. Journal of Financial Economics, 3(4), 305- 360. https://doi.org/10.1016/0304-405X(76)90026-X.

John, T., and John, K., 1993. Top-management compensation and capital structure, Journal of Finance, 48, 949-974. https://doi.org/10.1111/j.1540-6261.1993.tb04026.x. 
Johnston, D., 2006. Managing stock option expense: The manipulation of option pricing model assumptions. Contemporary Accounting Research, 23(2), 395-425. https://doi.org/10.1506/6YVX-9KDJ-08UC-P0Q6.

Kothari, S. P., Zimmerman, J. L., 1995. Price and return models. Journal of Accounting and Economics, 20(2), 155-192. https://doi.org/10.1016/0165-4101(95)00399-4.

Kousenidis, D. V., Ladas, A. C., Negakis, C. I., 2013. The effects of the European debt crisis on earnings quality. International Review of Financial Analysis, 30, 351-362. https://doi.org/10.1016/j.irfa.2013.03.004.

La Porta, R., Lopez-de-Silanes, F., Shleifer, A., Vishny, R. W., 1998. Law and finance. Journal of Political Economy, 106(6), 1113-1155. https://doi.org/10.1086/250042.

Lam, S.S., Chng, B.F., 2006. Do executive stock option grants have value implications for firm performance? Review of Quantitative Finance and Accounting, 26(3), 249-274. https://doi.org/10.1007/s11156-006-7433-3.

Landsberg, R. D., 2004. Stock option valuation and planning opportunities. Journal of Financial Service Professionals, 58(6), 30-32.

Landsman, W. R., Peasnell K. V., Pope P. F., Yeh, S., 2006. Which approach to accounting for employee stock options best reflects market pricing? Review of Accounting Studies, 11(2), 203245. https://doi.org/10.1007/s11142-006-9008-x.

Lev B., 2001. Intangibles: Management, measurement, and reporting. The Brookings Institution.

Li, H., 2003. Employee stock options, residual income valuation, and stock price reaction to SFAS footnote disclosures. working paper, Santa Clara University. Available at: http://papers.ssrn.com/sol3/papers.cfm?abstract id=376580.

Liao, L., Morris, R., Kang, H., Tang, Q., 2013. Information asymmetry of fair value accounting during the global financial crisis. Journal of Contemporary Accounting and Economics, 9 (2), 221-236. https://doi.org/10.1016/j.jcae.2013.10.001.

Mathieu, M., 2012. Annual economic survey of employee ownership in European countries 2012. European federation of employee share ownership.

Matolcsy, Z., Riddell, S., Wright, A., 2009. Alternative explanations for the association between market values and stock based compensation expenditure, Journal of Contemporary Accounting \& Economics, 5(2), 95-107. https://doi.org/10.1016/j.jcae.2009.09.001. 
Mehran, H., Rosenberg. J., 2009. The Effect of CEO stock options on bank investment choice, borrowing, and capital. Working paper, Federal Reserve Bank of New York, Staff report No. 305. http://dx.doi.org/10.2139/ssrn.1022972.

Merton, R. C., 1973. Theory of Rational Option Pricing, The Bell Journal of Economics and Management Science, 4 (1), 141-183. Doi: 10.2307/3003143.

Morris, R.D., Kang, H. Jie, J., 2016. The determinants and value relevance of banks' discretionary loan loss provisions during the financial crisis. Journal of Contemporary Accounting \& Economics, 12(2), 176-190. https://doi.org/10.1016/j.jcae.2016.07.001.

Murphy, K.J., 1999. Executive compensation, In: Orley, A., David, C. (Eds.). Handbook of Labor Economics, Vol. 3. North-Holland, Amsterdam.

Niu, F., Xu, B., 2009. Does recognition versus disclosure really matter? Evidence from market valuation of recognition of employee stock option expenses. Asia Pacific Journal of Accounting and Economics, 16(2), 215-233. https://doi.org/10.1080/16081625.2009.9720838.

Ohlson, J. A., 1995. Earnings, book values, and dividends in equity valuation. Contemporary Accounting Research, 11(2), 661-687. https://doi.org/10.1111/j.1911-3846.1995.tb00461.x.

Paul, J., 1992. On the efficiency of stock-based compensation. Review of Financial Studies 5, 471-502. https://doi.org/10.1093/rfs/5.3.471.

Pesaran, M. H., 2006. Estimation and inference in large heterogeneous panels with a multifactor error structure. Econometrica, 74, 967-1012. https://doi.org/10.1111/j.1468-0262.2006.00692.x.

Ratliff, P. A., 2005. Reporting employee stock option expenses: is the debate over? The CPA Journal, 75(11), 38-43.

Rees, L., Stott, D., 2001. The value relevance of stock-based employee compensation disclosures. The Journal of Applied Business Research, 17(2), 105-116. https://doi.org/10.19030/jabr.v17i2.2077.

Sautner, Z., Weber, M., 2015. Corporate governance and the design of stock option contracts. Working paper. In AFA 2007 Chicago Meetings Pape. http://dx.doi.org/10.2139/ssrn.825429.

Schiemann, F., Guenther, T., 2013. Earnings predictability, value relevance, and employee expenses. The International Journal of Accounting, 48(2)149-172. https://doi.org/10.1016/j.intacc.2013.04.001.

Shivdasani, A., Yermack, D., 1999. CEO Involvement in the Selection of New Board Members: An Empirical Analysis. Journal of Finance 54(1), 1829-1853. https://doi.org/10.1111/0022$\underline{1082.00168 .}$. 
Shleifer, A., Vishny R. W., 1997. A survey of corporate governance”, Journal of Finance, 52(2), pp. 737-783. https://doi.org/10.1111/j.1540-6261.1997.tb04820.x.

Shleifer, A., Vishny, R. W., 1986. Large shareholders and corporate control. The Journal of Political Economy, 94(3), 461-488. https://doi.org/10.1086/261385.

Skinner, D. J., 1996. Are Disclosures about bank derivatives and employee stock options 'value relevant'? Journal of Accounting and Economics, 22(1-3), 393-405. https://doi.org/10.1016/S0165-4101(96)00432-6.

Street, D. and Cereola, S. 2004. Stock option compensation: Impact of expense recognition on performance indicators of non-domestic companies listed in the U.S, Journal of International Accounting, Auditing and Taxation, 13 (1): 21-37. https://doi.org/10.1016/j.intaccaudtax.2004.02.004.

Tsalavoutas, I., André, P., Evans, L., 2012. The transition to IFRS and the value relevance of financial statements in Greece. British Accounting Review, 44 (1), 262-277. https://doi.org/10.1016/j.bar.2012.09.004.

Yermack, D., 1997. Good timing: CEO stock option awards and company news announcements. Journal of Finance, 52(2), 449-476. https://doi.org/10.1111/j.1540-6261.1997.tb04809.x. 
TABLES

Table 1

Number of firms and firm-year observations for each country in the sample

\begin{tabular}{lcccc}
\hline \multicolumn{1}{c}{ Country } & Firm & Percent & Observation & Percent \\
\hline Austria & 2 & 3.17 & 19 & 2.65 \\
Belgium & 3 & 4.76 & 32 & 4.46 \\
Denmark & 2 & 3.17 & 20 & 2.79 \\
Finland & 2 & 3.17 & 21 & 2.93 \\
France & 5 & 7.94 & 60 & 8.37 \\
Germany & 3 & 4.76 & 34 & 4.74 \\
Hungry & 1 & 1.59 & 12 & 1.67 \\
Ireland & 1 & 1.59 & 8 & 1.12 \\
Italy & 6 & 9.52 & 68 & 9.48 \\
Malta & 1 & 1.59 & 12 & 1.67 \\
Netherland & 4 & 6.35 & 48 & 6.69 \\
Poland & 5 & 7.94 & 60 & 8.37 \\
Portugal & 1 & 1.59 & 12 & 1.67 \\
Spain & 2 & 3.17 & 24 & 3.35 \\
Sweden & 2 & 3.17 & 24 & 3.35 \\
Switzerland & 8 & 12.70 & 94 & 13.11 \\
UK & 15 & 23.81 & 169 & 23.57 \\
\hline Total & 63 & 100 & 717 & 100 \\
\hline
\end{tabular}


Table 2

Descriptive statistics and correlation matrix

(Panel A) Descriptive statistics

\begin{tabular}{lcccccc}
\hline \multicolumn{1}{c}{ Stats } & $\mathrm{N}$ & Mean & $\mathrm{SD}$ & $\mathrm{p} 25$ & Median & $\mathrm{p} 75$ \\
\hline$R$ & 717 & 0.153 & 0.527 & -0.176 & 0.089 & 0.347 \\
$N I$ & 717 & 0.064 & 0.132 & 0.046 & 0.079 & 0.108 \\
$\triangle N I$ & 717 & 0.124 & 0.215 & 0.095 & 0.147 & 0.201 \\
SOBC & 717 & 0.005 & 0.007 & 0.001 & 0.002 & 0.005 \\
Large & 717 & 0.444 & 0.264 & 0.224 & 0.411 & 0.680 \\
SOBC $($ mil $€)$ & 717 & 87.267 & 233.686 & 0.796 & 5.000 & 36.937 \\
\hline
\end{tabular}

Table 2 (Panel B) Descriptive statistics pre-crisis, crisis and post-crisis

\begin{tabular}{lrrrrrrrrr}
\hline & \multicolumn{3}{c}{$\begin{array}{c}\text { Pre-Crisis (2005-2006) } \\
\text { N=115 }\end{array}$} & \multicolumn{4}{c}{$\begin{array}{c}\text { Crisis (2007-2011) } \\
\text { N = 315 }\end{array}$} & \multicolumn{4}{c}{ Post-Crisis (2012-2016) } \\
\multicolumn{1}{c}{ Stats } & Mean Median & SD & Mean & Median & SD & Mean & Median & SD \\
\hline$R$ & 0.337 & 0.248 & 0.417 & 0.079 & -0.106 & 0.665 & 0.160 & 0.146 & 0.348 \\
NI & 0.119 & 0.105 & 0.067 & 0.059 & 0.073 & 0.129 & 0.048 & 0.072 & 0.148 \\
SNI & 0.205 & 0.193 & 0.109 & 0.123 & 0.136 & 0.220 & 0.092 & 0.134 & 0.231 \\
SOBC & 0.003 & 0.002 & 0.004 & 0.005 & 0.002 & 0.008 & 0.005 & 0.002 & 0.006 \\
SOBC (mil $€)$ & 65.169 & 5.502 & 200.362 & 88.393 & 4.065 & 251.149 & 94.887 & 7.338 & 226.285 \\
\hline
\end{tabular}

Table 2 (Panel C) Correlation Matrix

\begin{tabular}{|c|c|c|c|c|c|}
\hline & $R$ & $N I$ & $\Delta N I$ & $S O B C$ & Large \\
\hline$R$ & 1 & & & & \\
\hline$N I$ & $0.2032 * * *$ & 1 & & & \\
\hline$\Delta N I$ & $0.077 * *$ & $0.8676 * * *$ & 1 & & \\
\hline$S O B C$ & $0.172 * * *$ & 0.0108 & -0.0004 & 1 & \\
\hline Large & 0.0254 & -0.0261 & -0.0339 & $-0.2593 * * *$ & 1 \\
\hline
\end{tabular}

Notes: $R$ is the annual share return inclusive of dividends and measured as the 12-month return ending three months after the end of the fiscal year. NI is the net income before the recognised share-option based compensation expense over the fiscal year and divided by the market value of equity at the beginning of the year. $\triangle N I$ is the change in $N I$ in the current year. $S O B C$ refers to the recognised expense of SOBC schemes over the year divided by the market value of equity at the beginning of the year. Large is the percentage of shares held by large shareholder (those hold 5\% or more of ordinary shares). 
Table 3

The relationship between $\mathrm{SOBC}$ and stock return in the crisis and the effect of ownership concentration

\begin{tabular}{|c|c|c|c|}
\hline & $\begin{array}{l}\text { Panel (A) Full sample } \\
\text { period }\end{array}$ & Panel (B) Crisis effect & $\begin{array}{c}\text { Panel (C) Crisis and } \\
\text { Large shareholders } \\
\text { effect }\end{array}$ \\
\hline$N I$ & $\begin{array}{c}2.175 * * * \\
(0.274)\end{array}$ & $\begin{array}{c}2.120 * * * \\
(0.267)\end{array}$ & $\begin{array}{c}2.143 * * * \\
(0.275)\end{array}$ \\
\hline$\Delta N I$ & $\begin{array}{c}-0.970 * * * \\
(0.214)\end{array}$ & $\begin{array}{c}-0.964 * * * \\
(0.217)\end{array}$ & $\begin{array}{c}-0.968 * * * \\
(0.217)\end{array}$ \\
\hline$S O B C$ & $\begin{array}{c}12.69 * * * * \\
(3.274)\end{array}$ & $\begin{array}{c}4.727 * * \\
(1.942)\end{array}$ & $\begin{array}{c}3.851 \\
(4.573)\end{array}$ \\
\hline CRISIS & & $\begin{array}{c}-0.0660 * * \\
(0.0336)\end{array}$ & $\begin{array}{l}-0.0183 \\
(0.0730)\end{array}$ \\
\hline Large & & & $\begin{array}{c}0.000950 \\
(0.000782)\end{array}$ \\
\hline CRISIS*SOBC & & $\begin{array}{c}14.35 * * * \\
(3.396)\end{array}$ & $\begin{array}{c}2.444 \\
(4.398)\end{array}$ \\
\hline Large *SOBC & & & $\begin{array}{l}0.0828 \\
(0.120)\end{array}$ \\
\hline Large $^{*}$ CRISIS & & & $\begin{array}{l}-0.00144 \\
(0.00176)\end{array}$ \\
\hline $\operatorname{Large}^{*}$ CRISIS $* S O B C$ & & & $\begin{array}{c}0.443 * * * \\
(0.131)\end{array}$ \\
\hline Constant & $\begin{array}{c}0.0755^{* *} * \\
(0.0329)\end{array}$ & $\begin{array}{c}0.110 * * * \\
(0.0336)\end{array}$ & $\begin{array}{c}0.0595 \\
(0.0478)\end{array}$ \\
\hline Observations & 717 & 717 & 717 \\
\hline R-squared & 0.109 & 0.117 & 0.131 \\
\hline
\end{tabular}

Notes: Panel (A) provides the result of the OLS regression that test the relationship between the recognised expense of SOBC schemes and shareholder returns. Panel (B) provides the result of the OLS regression that examines the impact of the financial crisis period (2007-2011) on the relationship between the recognised expense of SOBC schemes and shareholder returns. Finally, Panel (C) provides the result of the OLS regression that examines the effect of the percentage of shares held by large shareholders on the relationship between SOBC expense and shareholder returns in the crisis period. The sample includes 717 firm-years of 63 distinct financial firms for the period between 2005 and 2016. The variables are identified as follows: $R_{i t}$ is the annual share return inclusive of dividends for firm $i$ and measured as the 12-month return ending three months after the end of the fiscal year $t, N I_{i t}$ is the net income before the recognised SOBC expense for firm $i$ over the fiscal year $t$ and divided by the market value of equity at the beginning of year $t, \Delta N I_{i t}$ is the change in $N I_{i t}$ between year $t$ and $t-1, S O B C_{i t}$ refers to the recognised SOBC expense of firm $i$ over the year $t$ divided by the market value of equity at the beginning of year $t$, CRISIS is a dummy variable coded 1 for the years of crisis period (2007-2011) and 0 otherwise, non-crisis period (2005-2006 and 2012-2016), and Large $_{i t}$ is the percentage of shares held by large shareholders (those hold 5\% or more of ordinary shares) for firm $i$ at the end of year $t$. In parentheses robust standard errors are adjusted for two dimensions (both firms and countries). $* * * p<0.01, * * p<0.05$, $* \mathrm{p}<0.1$. 
Table 4

The relationship between SOBC expense and shareholder returns - Period by period analysis

\begin{tabular}{lcccc}
\hline & Coeff. & Panel (A) Pre-Crisis & Panel (B) Crisis & Panel (C) Post-Crisis \\
\hline$N I$ & $\alpha_{1}$ & $4.941 * * *$ & $2.387 * * *$ & $1.052^{* * *}$ \\
& & $(1.681)$ & $(0.387)$ & $(0.383)$ \\
$\Delta N I$ & $\alpha_{2}$ & $-2.327 * * *$ & $-1.215^{* * *}$ & -0.320 \\
& & $(0.896)$ & $(0.313)$ & $(0.237)$ \\
SOBC & $\alpha_{3}$ & $\mathbf{- 3 . 5 1 3}$ & $\mathbf{1 9 . 4 7 * * *}$ & $\mathbf{5 . 9 1 6 * * *}$ \\
& & $\mathbf{( 5 . 6 6 9 )}$ & $\mathbf{( 4 . 6 4 4 )}$ & $(\mathbf{1 . 8 7 3 )}$ \\
Constant & $\alpha_{0}$ & $0.237 * *$ & -0.00635 & $0.110 * * *$ \\
& & $(0.102)$ & $(0.0439)$ & $(0.0179)$ \\
Observations & & 115 & 315 & 287 \\
R-squared & & 0.101 & 0.143 & 0.079 \\
$\alpha_{3}$ (Crisis) $-\alpha_{3}$ (Pre- & $\mathbf{2 2 . 9 8 3 * * *}$ & & & \\
Crisis) & & & & \\
$\alpha_{3}$ (Crisis) $-\alpha_{3}$ (Post- & $\mathbf{1 3 . 5 5 4 * * *}$ & & & \\
Crisis) & & & & \\
\hline
\end{tabular}

Notes: This table provides the result of the OLS regressions that test the relationship between SOBC expense and shareholder returns over three periods: pre-crisis period (2005-2006); crisis period (2007-2011); and post-crisis period (2012-2016). The sample includes 63 distinct financial firms. The variables are identified as follows: $R_{i t}$ is the annual share return inclusive of dividends for firm $i$ and measured as the 12-month return ending three months after the end of the fiscal year $t, N I_{i t}$ is the net income before the recognised SOBC expense for firm $i$ over the fiscal year $t$ and divided by the market value of equity at the beginning of year $t, \Delta N I_{i t}$ is the change in $N I_{i t}$ between year $t$ and $t-1$, and $S O B C_{i t}$ refers to the recognised SOBC expense of firm $i$ over the year $t$ divided by the market value of equity at the beginning of year $t$. In parentheses robust standard errors are adjusted for two dimensions (both firms and countries). $* * * \mathrm{p}<0.01, * * \mathrm{p}<0.05, * \mathrm{p}<0.1$. 
Table 5

The relationship between SOBC expense and shareholder returns in the global financial crisis and sovereign debt crisis

\begin{tabular}{lccc}
\hline & $\begin{array}{c}\text { Panel (A) Pre-Crisis } \\
\text { and Financial Crisis }\end{array}$ & $\begin{array}{c}\text { Panel (B) Debt Crisis } \\
\text { and Post Crisis }\end{array}$ & $\begin{array}{c}\text { Panel (C) Debt Crisis } \\
\text { and Post Crisis } \\
\text { (Eurozone only) }\end{array}$ \\
\hline$N I$ & $3.458^{* * *}$ & $1.537 * * *$ & $1.457 * * *$ \\
& $(0.896)$ & $(0.259)$ & $(0.312)$ \\
& $-1.302 * * *$ & $-0.661 * * *$ & $-0.895 * * *$ \\
SOBC & $(0.492)$ & $(0.217)$ & $(0.263)$ \\
& -4.925 & $5.997 * * *$ & 5.311 \\
CRISIS & $(5.152)$ & $(2.026)$ & $(4.259)$ \\
& $-0.387 * * *$ & 0.0962 & 0.0248 \\
CRISIS*SOBC & $(0.120)$ & $(0.0600)$ & $(0.0530)$ \\
& $\mathbf{2 6 . 6 9 * * *}$ & $\mathbf{7 . 8 9 6 *}$ & $\mathbf{1 4 . 6 1 * * *}$ \\
Constant & $(\mathbf{6 . 6 7 7 )}$ & $\mathbf{( 4 . 7 2 9 )}$ & $\mathbf{5 . 4 9 6 )}$ \\
& 0.0391 & $0.117 * * *$ & $(0.03 * * *$ \\
Observations & $(0.0848)$ & $(0.0309)$ & 223 \\
R-squared & 241 & 476 & 0.110 \\
\hline
\end{tabular}

Notes: Panel (A) provides the result of the OLS regression that examines the relationship between SOBC expense and shareholder returns around the global financial crisis (2007-2008) for a sample of 63 European financial firms between 2005 and 2008. Panel (B) provides the result of the OLS regression that examines the relationship between SOBC expense and shareholder returns around European sovereign debt crisis period (2009-2011) for a sample of 63 European financial firms between 2009 and 2016. Panel (C) provides the result of the OLS regression that examines the relationship between SOBC expense and shareholder returns around European sovereign debt crisis (2009-2011) for a sample of 30 financial firms domiciled in the Eurozone between 2009 and 2016. The variables are identified as follows: $R_{i t}$ is the annual share return inclusive of dividends for firm $i$ and measured as the 12-month return ending three months after the end of the fiscal year $t, N I_{i t}$ is the net income before the recognised SOBC expense for firm $i$ over the fiscal year $t$ and divided by market value of equity at the beginning of year $t, \Delta N I_{i t}$ is the change in $N I_{i t}$ between year $t$ and $t$ $1, S O B C_{i t}$ refers to the recognised SOBC expense of firm $i$ over the year $t$ divided by the market value of equity at the beginning of year $t, C R I S I S$ is a dummy variable coded 1 for the years of crisis period, 2007-2008 in Panel (A) and 2009-2011 in Panel (B) and (C), and 0 otherwise. In parentheses robust standard errors are adjusted for two dimensions (both firms and countries). $* * * \mathrm{p}<0.01, * * \mathrm{p}<0.05, * \mathrm{p}<0.1$. 
Table 6

The relationship between $\mathrm{SOBC}$ expense and shareholder returns in the crisis - small vs large firms \& low growth vs high growth firms

\begin{tabular}{lcccc}
\hline & Small Firms & large Firms & low growth firms & $\begin{array}{c}\text { High growth } \\
\text { firms }\end{array}$ \\
\hline$N I$ & $2.189^{* * * *}$ & $1.890^{* * *}$ & $1.994 * * *$ & $2.371 * * *$ \\
& $(0.419)$ & $(0.464)$ & $(0.355)$ & $(0.619)$ \\
SNI & $-0.788^{* *}$ & $-1.016^{* * *}$ & $-1.004 * * *$ & -0.869 \\
& $(0.308)$ & $(0.299)$ & $(0.261)$ & $(0.544)$ \\
CRISIS & $9.656^{* * *}$ & 2.363 & 2.452 & $8.100^{* *}$ \\
& $(2.016)$ & $(1.905)$ & $(1.777)$ & $(3.678)$ \\
CRISIS*SOBC & -0.0435 & $-0.0964 * *$ & $-0.152 * * *$ & 0.0106 \\
& $(0.0624)$ & $(0.0443)$ & $(0.0420)$ & $(0.0397)$ \\
Constant & $\mathbf{6 . 9 9 8 * *}$ & $\mathbf{1 9 . 5 0 * * *}$ & $\mathbf{1 8 . 3 4 * * *}$ & $\mathbf{1 0 . 1 5 * * *}$ \\
& $(\mathbf{3 . 5 3 3 )}$ & $\mathbf{( 7 . 2 6 7 )}$ & $(\mathbf{4 . 8 2 1})$ & $(\mathbf{3 . 5 6 7 )}$ \\
Observations & $0.0726 * * *$ & $0.142^{* * *}$ & $0.143 * * *$ & $0.0621 * * *$ \\
R-squared & $(0.0172)$ & $(0.0457)$ & $(0.0467)$ & $(0.0217)$ \\
\hline
\end{tabular}

Notes: Panel (B) provides the result of the OLS regression that examines the impact of the financial crisis period (20072011) on the relationship between SOBC expense and shareholder returns after dividing the sample into small versus large firms as well as low versus high opportunity growth firms. The whole sample includes 717 firm-years of 63 distinct financial firms for the period between 2005 and 2016. Firms are classified as either small or large firms based on the median value of the average total assets over the study period. Firms are classified as either low or high opportunity growth firms based on the median value of average yearly market to book value ratio over the study period. The variables are identified as follows: $R_{i t}$ is the annual share return inclusive of dividends for firm $i$ and measured as the 12-month return ending three months after the end of the fiscal year $t, N I_{i t}$ is the net income before the recognised SOBC expense for firm $i$ over the fiscal year $t$ and divided by the market value of equity at the beginning of year $t$, $\Delta N I_{i t}$ is the change in $N I_{i t}$ between year $t$ and $t-1, S O B C_{i t}$ refers to the recognised SOBC expense of firm $i$ over the year $t$ divided by the market value of equity at the beginning of year $t$, and CRISIS is a dummy variable coded 1 for the years of crisis period (2007-2011) and 0 otherwise, non-crisis period (2005-2006 and 2012-2016). In parentheses robust standard errors are adjusted for two dimensions (both firms and countries). $* * * \mathrm{p}<0.01, * * \mathrm{p}<0.05,{ }^{*} \mathrm{p}<0.1$.

Table 7: The relationship between SOBC and stock return in the crisis and the effect of 
ownership concentration - controlling for self-selection bias using Heckman's estimation

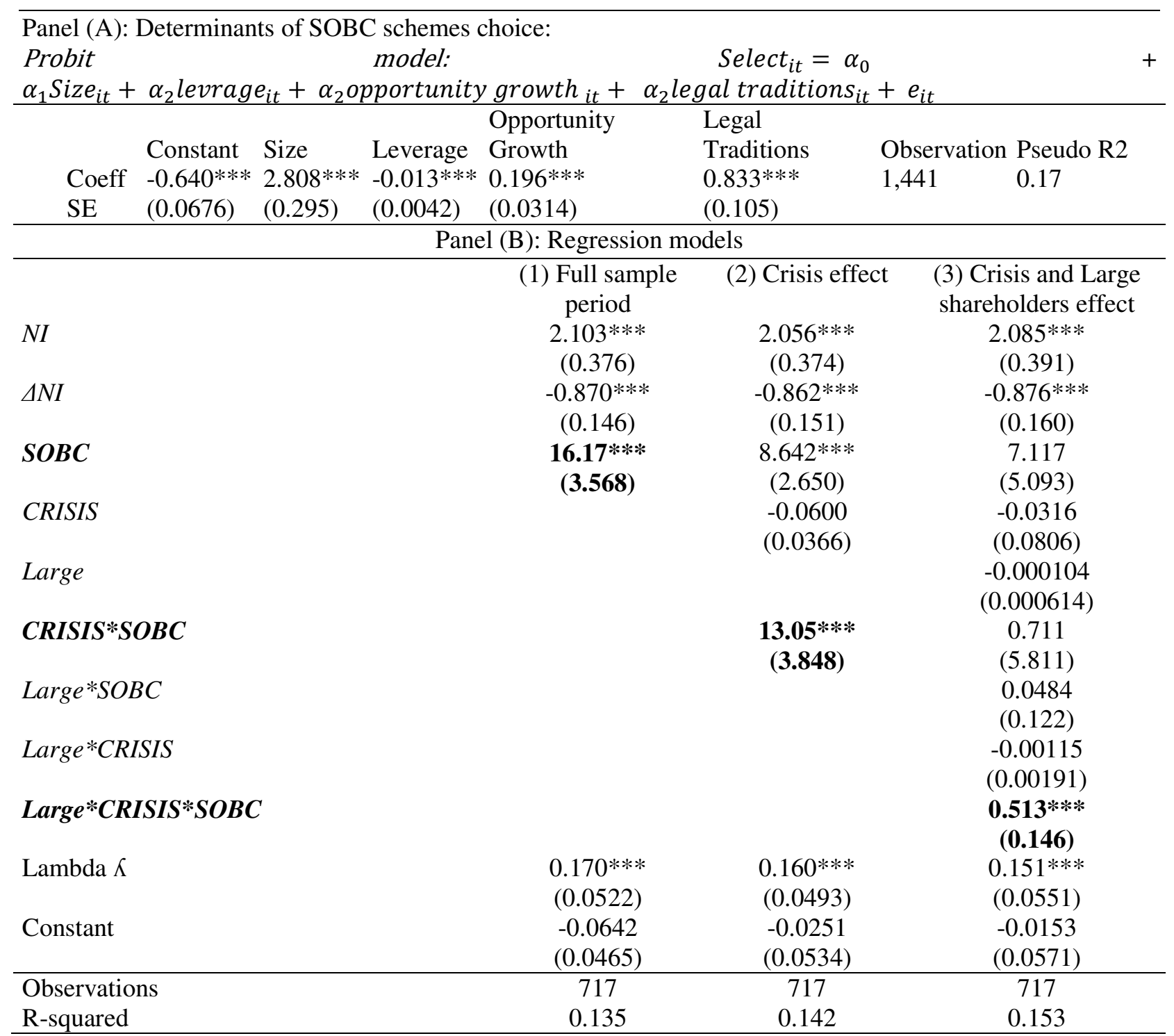

Panel A reports the results from the first step Probit regression on a sample of 1,441 observations which comprises 62 financial institutions (724 observations) that did not use SOBC schemes, and 63 financial institutions (717 observations) that use SOBC schemes over the sample period. The dependent variable, Select, is a dummy variable equal to 1 for our selected sample firms, and 0 otherwise. The independent variables in this equation are the main determinants of using SOBC schemes. Following prior studies such as Core and Guay (2001) and Alhaj-Ismail et al. (2018), we predict that the decision to use SOBC schemes is a function of the following factors: (i) firm size, measured by the lagged total assets, (ii) firm leverage, measured by firm total debt divided by shareholders equity, (iii) firm opportunity growth, measured as the lagged market to book value ratio, (iv) legal traditions under which a financial firm operates, is dummy variable equal to 1 if the financial institution is domiciled in a common-law country and 0 if it is domiciled in a codelaw country.

Panel (B) variable definitions are similar to those defined in table (3). It also includes the Inverse Mills Ratio, denoted by Lambda, for each of the 717 firm-year observations in our primary sample computed using the first-stage probit estimation. Hence, the results reported in panel (B), equations (1, $2 \& 3$ ) control for self-selection bias using the Heckman (1979) two-stage procedure. In parentheses robust standard errors are adjusted for two dimensions (both firms and countries). $* * * \mathrm{p}<0.01, * * \mathrm{p}<0.05, * \mathrm{p}<0.1$. 